\title{
POTENSI EKSTRAK DAUN CENDANA (Santalum album L.) SEBAGAI SENYAWA PENGHAMBAT JAMUR Candida albicans
}

\author{
K. Swandiyasa*, N. M. Puspawati, dan I. A. R. A. Asih \\ Program Studi Kimia, Fakultas Matematika dan Ilmu Pengetahuan Alam, Universitas Udayana \\ Jalan Kampus Unud-Jimbaran, Jimbaran-Bali, Indonesia \\ *e-mail: swandiyasa1@gmail.com
}

\begin{abstract}
ABSTRAK
Penyakit yang disebabkan oleh jamur Candida albicans (C.albicans) seperti penyakit mulut, kulit dan kuku masih banyak ditemui di Indonesia. Penelitian ini bertujuan untuk menguji aktivitas antijamur ekstrak $n$-heksana, kloroform, dan $n$-butanol daun cendana dalam menghambat pertumbuhan jamur $C$. albicans dan menentukan konsentrasi hambat minimum ekstrak yang paling aktif serta mengidentifikasi senyawa aktifnya. Pengujian aktivitas antijamur dilakukan dengan metode difusi cakram dan identifikasi senyawa aktif dengan LC-MS/MS. Maserasi $1 \mathrm{~kg}$ serbuk daun cendana dengan metanol menghasilkan 86,80 g ekstrak kental metanol. Partisi terhadap $40 \mathrm{~g}$ ekstrak kental metanol dengan $n$-heksana, kloroform, dan $n$-butanol diperoleh 12,60 g ekstrak $n$ heksana, 6,20 g kloroform, dan 1,20 g $n$-butanol. Hasil uji aktivitas antijamur menunjukkan ekstrak $n$-heksana mampu menghambat pertumbuhan jamur C.albicans dengan diameter hambat terbesar yaitu $13 \mathrm{~mm}$, diikuti dengan kloroform $9 \mathrm{~mm}$, dan $n$-butanol $8 \mathrm{~mm}$. Ekstrak aktif n-heksana yang aktif sebagai antijamur selanjutnya dibuatkan variasi konsentrasi untuk mendapatkan daya hambat minimum. Pada konsentrasi 95, 90 dan $85 \%$ ekstrak n-heksana memberikan daya hambat berturut-turut sebesar 12,04, 15,8, dan $13 \mathrm{~mm}$. Sementara pada konsentrasi $80 \%$ memberikan daya hambat minimum dengan diameter hambat sebesar 9,32 mm. Analisis spektra massa dari dua puncak kromatogram hasil LC-MS/MS dengan program MassLynx V4.1 dan berdasarkan database web Chemspider, maka ekstrak $n$-heksana daun cendana diduga mengandung senyawa benzofurazan dan 2-picolylamine yang aktif sebagai antijamur.
\end{abstract}

Kata kunci: Candida.albicans, daun cendana (Santalum album L.), penghambat jamur

\begin{abstract}
Diseases caused by C. albicans (C. albicans) such as mouth, skin and nail diseases are still commonly found in Indonesia. This study aimed to examine antifungal activity of n-hexane, chloroform, and n-butanol extracts of Santalum album (S.album) leaves in inhibiting the growth of C. albicans and to determine the minimum inhibitory concentration of the most active extract as well as to identify their active compounds. Antifungal activity testing was carried out using disc diffusion method and identification of active compound was performed using LC-MS /MS. Extraction of $1 \mathrm{~kg}$ sandalwood leaf powder with methanol yielded 86.80 gram of crude methanol extract. Partiiton 40 gram of the crude methanol extract with n-hexane, chloroform, and n-buthanol gave $12.60,6.20$ and $1.20 \mathrm{~g}$ of extracts respectively. The antifungal activity test results revealed that $\mathrm{n}$-hexane extract was the most active in inhibiting the growth of C.albicans with inhibitory diameter of $13 \mathrm{~mm}$ as compared to chloroform $9 \mathrm{~mm}$ and n-buthanol $8 \mathrm{~mm}$. The active n-hexane extract which is active as an antifungal is then made various variations to obtain a minimum inhibitory. The n-hexane extract, at concentrations of 95,90 and $85 \%$ inhibited the growth of C.albican with inhibitory diameter of $12.04,15.8$, and $13 \mathrm{~mm}$ respectively. While at the concentarion of $80 \%$ showed minimum inhibitory diameter of $9.32 \mathrm{~mm}$. Based on analysis mass spectra of two peaks of LC-MS / MS chromatogram with MassLynx V4.1 programe and Chemspider web database suggested the presence of benzofurazan and picolylamine compounds which may contribute to the antifungal activityof n-hexane extract of S.album.
\end{abstract}

Keywords: Sandalwood (Santalum album L.), antifungal, C. albicans, n-Hexane, LC-MS/MS

\section{PENDAHULUAN}

Penyakit mulut, kulit dan kuku yang disebabkan oleh infeksi jamur C. albicans masih sering ditemui di Indonesia. Hal ini disebabkan kerena negara Indonesia beriklim tropis dengan kelembaban udara yang tinggi, kepadatan penduduknya yang juga tinggi, dan kurangnya kesadaran akan kebersihan lingkungan atau sanitasi sehingga pertumbuhan jamur dapat berkembang dengan pesat (Mutiawati, 2016).

Candida albicans merupakan salah satu penyebab infeksi jamur yang biasanya ditemukan di dalam rongga mulut dan bersifat oppurtunistik. Apabila keseimbangan flora dan 
kebersihan mulut terganggu atau daya tahan tubuh melemah (immunodeficiency) maka C.albicans dapat menimbulkan infeksi seperti penyakit mulut, kulit, kuku, septikemia, endokarditis, meningitis, dan genitalia (Ahsani, 2014).

Infeksi yang disebabkan oleh jamur dapat diobati dengan suatu senyawa yang mampu mendenaturasi protein sel sehingga dinding sel jamur mengalami lisis serta mengganggu permeabilitas sel. Senyawa ini dikenal sebagai senyawa antijamur. Golongan antijamur yang berkembang dan umum digunakan di masyarakat antara lain nystatin, ketokonasol, dan mikonasol. Beberapa antijamur dari golongan flukonasol, intrakonasol dan ampoterisin B. dilaporkan resisten terhadap C.albicans. Selain itu, penggunaan antijamur ini dalam dosis tinggi dan secara terus menerus dapat menyebabkan rasa gatal, mual, muntah, dan diare (Tripathi, 1999).

Salah satu upaya pencarian serta pengembangan antijamur yang memiliki efek samping minimum adalah dengan memanfaatkan bahan alam salah satunya dari tumbuhan. Tumbuhan yang berpotensi sebagai antijamur adalah cendana (Santalum album L.). Pada umumnya, bagian tumbuhan cendana yang banyak dimanfaatkan adalah minyak atsiri, ekstrak kayu dan akarnya. Kumar et al, 2015 melaporkan aktivitas antijamur minyak atsiri kayu cendana terhadap $M$. canis, Trichophytonmentagrophytes, dan T. rubrum tetapi tidak efektif terhadap jamur C.albicans, A. niger, dan A. fumigatesc. Sementara itu, ekstrak aseton batang cendana yang mengandung senyawa steroid, triterpenoid, alkaloid, flavonoid, saponin, diterpen, dan glikosida dilaporkan aktif sebagai antijamur terhadap C. albicans (Rakesh, et al., 2010). Monika, 2017, melaporkan kandungan fitokimia ekstrak metanol daun cendana yang meliputi steroid, triterpenoid, alkaloid, fenol, dan flavonoid. Senyawa ini berpotensi sebagai antijamur sehingga perlu diteliti aktivitas antijamurnya. Sejauh ini belum ada penelitian yang mengkaji potensi ekstrak daun cendana sebagai antijamur terhadap C.albicans.

Penelitian ini bertujuan untuk meneliti potensi ekstrak n-heksana, kloroform, dan nbutanol sebagai antijamur terhadap $C$. albicans dan mengidentifikasi kandungan senyawa pada ekstrak yang aktif dengan spektrometri LCMS/MS.

\section{MATERI DAN METODE}

\section{Bahan}

Bahan-bahan yang digunakan yaitu Daun cendana (Santalum album L.) diperoleh dari hutan cendana So'e, NTT, isolat jamur $(C$. albicans L.), metanol teknis $96 \%, \mathrm{FeCl}_{3}$, serbuk $\mathrm{Mg}, \mathrm{HCl}$ pekat, pereaksi Mayer, asam asetat anhidrat, asam sulfat, aquades, nheksana, kloroform, dan n-butanol.

\section{Peralatan}

Peralatan yang digunakan dalam penelitian ini antara lain gelas beker, gelas ukur, labu erlenmeyer, pipet tetes, spatula, blender, toples kaca, corong pisah, plat tetes, labu ukur, pipet volume, pipet mikro, rotary vacuum evaporator, neraca analitik, gunting, mistar, kain kasa, aluminium foil, penangas air, pinset, cawan petri, tabung reaksi, dan instrumen LC-MS/MS (Acquity).

\section{Cara Kerja}

\section{Pembuatan Ekstrak}

Daun cendana (Santalum album L.) dibersihkan kemudian dipisahkan dari batangnya lalu dipotong dengan ukuran yang lebih kecil. Daun cendana dikeringkan pada suhu ruangan dengan cara diangin-anginkan. Setelah kering daun diblender sehingga diperoleh serbuk daun cendana. Sebanyak $1 \mathrm{~kg}$ serbuk daun cendana kering dimaserasi dengan metanol teknis $96 \%$. Proses ekstraksi dilakukan sebanyak 3 kali sirkulasi $(3 \times 24$ jam $)$. Selanjutnya ekstrak disaring untuk mendapatkan filtrat (ekstrak cair). Selanjutnya filtrat yang diperoleh dikumpulkan dan pelarutnya diuapkan dengan vacuum rotary evaporator sehingga diperoleh ekstrak kental metanol. Ekstrak pekat metanol yang diperoleh ditimbang dan dimasukkan ke dalam wadah steril.

Ekstrak kental metanol kemudian dilarutkan menggunakan pelarut metanol-air dengan perbandingan 3:7 dan metanolnya dievaporasi hingga diperoleh ekstrak air.

Ekstrak air kemudian dipartisi dengan nheksana, kloroform, dan n-butanol dengan menggunakan corong pisah. Ekstrak hasil partisi dievaporasi sehingga didapatkan ekstrak pekat n-heksana, kloroform, dan n-butanol. 
pada konsentrasi $100 \%$ dan kontrol positif mikonasol $2 \%$ menunjukkan daya hambat terhadap pertumbuhan C. albicans.

Ekstrak n-heksana menghasilkan diameter hambat $13 \mathrm{~mm}$, relatif lebih besar dibandingkan kloroform dan n-butanol namun tergolong kategori sedang dalam menghambat pertumbuhan jamur C.albicans. Ekstrak kloroform dan n-butanol dengan diameter hambat berturut-turut 9 dan $8 \mathrm{~mm}$ tergolong lemah dalam menghambat pertumbuhan C.albicans sehingga ekstrak n-heksana merupakan ekstak yang relatif paling aktif dalam menghambat C.albicans dibandingkan dengan ekstrak lainnya.

\section{Uji Daya Hambat Minimum Ekstrak Daun Cendana}

Konsentrasi hambat minimum merupakan konsentrasi terendah yang masih mampu menghambat pertumbuhan jamur. Penentuan konsentrasi daya hambat minimum ini dilakukan untuk mengetahui konsentrasi minimum ektrak $n$-heksana daun cendana yang dapat menghambat pertumbuhan $C$. albicans. Hasil uji aktivitas antijamur ekstrak n-heksana pada konsentrasi 95, 90, 85, 80, 70, $60 \%$ dan kontrol positif mikonasol dapat dilihat pada Tabel 1. dan pada Gambar 1. dan 2.

Tabel 1. Hasil uji aktivitas antijamur ekstrak nheksana daun cendana terhadap $C$. albicans pada berbagai konsentrasi

\begin{tabular}{ccc}
\hline No. & Konsentrasi (\%) & Diameter zona hambat (mm) \\
\hline 1. & Mikonasol 2 & 18 \\
2. & 95 & 12,04 \\
3. & 90 & 15,8 \\
4. & 85 & 13 \\
5. & 80 & 9,32 \\
6. & 70 & 0 \\
7 & 60 & 0 \\
8 & Tween 10 & 0 \\
\hline
\end{tabular}

Hasil uji aktivitas antijamur ekstrak $n$ heksana daun cendana seperti tertera pada Tabel 4.2, pada konsentrasi 95, 90 dan 85\%, memberikan diameter zona hambat berturutturut sebesar 12,04, 15,8 dan $13 \mathrm{~mm}$ yang termasuk kategori sedang dalam menghambat pertumbuhan jamur C.albicans. Pada konsentrasi $80 \%$, ekstrak $n$-heksana daun cendana memiliki diameter zona hambat sebesar 9,32 $\mathrm{mm}$ yang termasuk kategori lemah. Pada konsentrasi yang lebih rendah yaitu $70 \%$ dan $60 \%$ ekstrak n-heksana tidak menunjukkan adanya zona hambat $(0 \mathrm{~mm})$ sehingga konsentrasi $80 \%$ merupakan konsentrasi hambat minimum n-heksana untuk C.albicans. Kontrol negatif tween $10 \%$ tidak menunjukkan daya hambat.

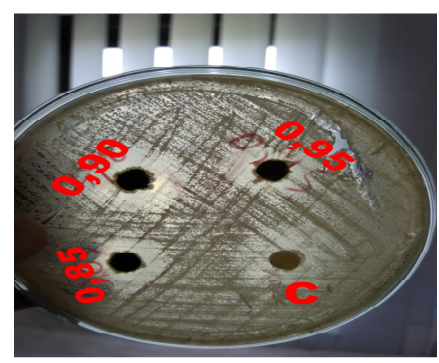

Gambar 1. Hasil uji aktivitas antijamur pada konsentrasi 95, 90, dan $85 \%$

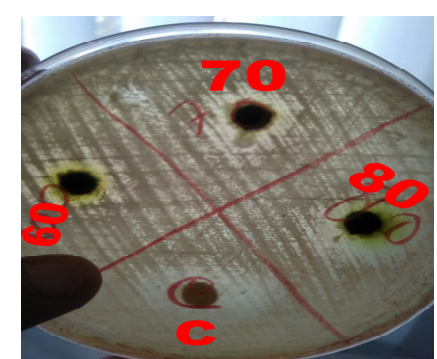

Gambar 2. Hasil uji aktivitas antijamur pada konsentrasi 80, 70 dan 60\%

Mekanisme penghambatan terhadap sel jamur bervariasi. Djunaedy (2008) menyatakan bahwa mekanisme kerja senyawa antijamur yakni dengan merusak membran sel jamur, menetralisir enzim yang terkait dalam proses invasi jamur, menghambat sistem enzim jamur sehingga mengganggu terbentuknya ujung hifa dan mempengaruhi sintesis asam nukleat dan protein.

\section{Uji Fitokimia Ekstrak n-Heksana Daun Cendana}

Hasil uji fitokimia ekstrak n-heksana daun cendana dapat dilihat pada Tabel 2.

Tabel 2. Hasil Uji Fitokimia Ekstrak nHeksana Daun Cendana

\begin{tabular}{cccc}
\hline Uji Fitokimia & Pereaksi & Perubahan yang terjadi & Keterangan \\
\hline Polifeno1 & FeCL $_{3}$ & Biru kehitaman & Positif \\
\hline Flavonoid & $\begin{array}{c}\text { Wilstater } \\
\text { Bate Smite- } \\
\text { Metcalfe } \\
\text { NaOH 10\% }\end{array}$ & $\begin{array}{c}\text { Tidak terjadi perubahan } \\
\text { Tidak terjadi perubahan }\end{array}$ & \\
& Tidak terjadi perubahan & Negatif \\
\hline Saponin & $\begin{array}{c}\text { Aquades dan HC1 } \\
\text { encer }\end{array}$ & Tidak terjadi perubahan & Negatif \\
\hline Alkaloid & $\begin{array}{c}\text { Wagner } \\
\text { Meyer }\end{array}$ & $\begin{array}{c}\text { Endapan Coklat } \\
\text { Endapan Putih }\end{array}$ & Positif \\
\hline Steroid & $\begin{array}{c}\text { Libermann } \\
\text { Burchad }\end{array}$ & Tidak terjadi perubahan & Negatif \\
\hline Terpenoid & $\begin{array}{c}\text { Libermann } \\
\text { Burchad }\end{array}$ & Merah keunguan & Positif \\
\hline
\end{tabular}


Dari data hasil uji fitokimia seperti disarikan pada Tabel 2, ekstrak n-heksana mengandung senyawa polifenol, alkaloid, dan terpenoid. Senyawa-senyawa ini berpotensi sebagai antijamur.

\section{Hasil identifikasi Ekstrak n-heksana daun cendana dengan LC-MS/MS}

Dari hasil identifikasi ekstrak n-heksana menggunakan LC-MS diperoleh kromatogram dengan 2 puncak dengan waktu retensi 11.69 dan 15.16 menit. Puncak ini selanjutnya diidentifikasi dengan cara menganalisis spektrum massanya. Hasil analisis spektrum massa masing-masing puncak kemudian dibandingkan dengan spektrum massa yang terdapat dalam web database chemspider, sehingga dapat diduga senyawa-senyawa yang terdapat dalam ekstrak n-heksana daun cendana. Perkiraan senyawa berdasarkan database dapat dilihat pada Tabel 3.

Tabel 3. Perkiraan senyawa hasil identifikasi dengan LC-MS/MS berdasarkan database

\begin{tabular}{llllll}
\hline No. & $\begin{array}{l}\text { Puncak } \\
\text { Senyawa }\end{array}$ & $\begin{array}{l}\text { Waktu } \\
\text { Retensi }\end{array}$ & $\mathrm{M}^{+}$ & Senyawa Dugaan & $\begin{array}{l}\text { Golongan } \\
\text { Senyawa }\end{array}$ \\
\hline 1 & Puncak 1 & 11,69 & 121.0442 & Benzofurazan & Alkaloid \\
2 & Puncak 2 & 15,16 & 109.1163 & 2-Picolylamine & Alkaloid \\
\hline
\end{tabular}

Komposisi Senyawa yang Terkandung pada Ekstrak n-Heksana Daun Cendana yang Bersifat Aktif Antijamur

Berdasarkan hasil analisis data kromatogram dan spektra massa dari LCMS/MS dengan program Masslynx dan web database chemspider, teridentifikasi 2 senyawa yaitu benzofurazan dan picolylamine.

Senyawa benzofurazan memiliki ion molekul $\left(\mathrm{M}^{+}\right)$dengan $\mathrm{m} / \mathrm{z}$ yaitu 120 dan pola pemenggalan spektra seperti yang ditunjukkan pada Tabel 4.

Tabel 4. Pola fragmentasi pada senyawa benzofurazan

\begin{tabular}{lllll}
\hline No. & $\mathbf{m} / \mathbf{z}$ & Kemungkinan fragmen yang hilang & & Penggalan \\
\hline $\mathbf{l}$ & 120 & $\mathrm{M}^{+}$ & & $\mathrm{C}_{6} \mathrm{H}_{4} \mathrm{~N}_{2} \mathrm{O}$ \\
\hline $\mathbf{2}$ & 90 & $\mathrm{M}^{+}-30$ & $-\mathrm{NO}$ & $\mathrm{C}_{6} \mathrm{H}_{5} \mathrm{~N}$ \\
\hline $\mathbf{3}$ & 63 & $\left(\mathrm{M}^{+}-30\right)-27$ & $-\mathrm{C}_{2} \mathrm{H}_{3}$ & $\mathrm{C}_{4} \mathrm{H}_{2} \mathrm{~N}$ \\
\hline
\end{tabular}

Pendekatan struktur ini dikonfirmasi dengan pola pemenggalan yang kemungkinan terjadi pada senyawa Benzofurazan yaitu sebagai berikut :

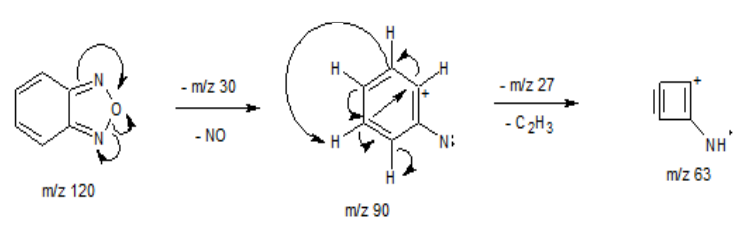

Benzofurazan merupakan senyawa yang memiliki rangka yang lebih stabil dan menunjukkan aktivitas dengan selektivitas yang tinggi terhadap jamur $C$. albicans (Wang et al., 2014).

Senyawa picolylamine merupakan salah satu aktivator enzim carbonic anhydrase (CA) dan menunjukkan potensi sedang sebagai aktivator (Innocenti et al., 2009). Enzim carbonic anhydrase merupakan enzim yang mengkatalisis reaksi pembentukan bikarbonat dari karbondioksida dan air. Enzim ini berperan penting dalam siklus hidup jamur patogen, regulasi biosintesis kapsil, filamentasi, dan adaptasi beberapa organisme terhadap $\mathrm{pH}$ dan konsentrasi $\mathrm{CO}_{2}$ pada tempat jamur ini tumbuh. Pada jamur C.albicans enzim yang berperan adalah CaNce103, aktivator enzim ini berperan penting dalam penghambatan pembentukan filamen jamur $C$. albicans, karena $\mathrm{CO}_{2}$ merupakan promotor kuat dari pembentukan filament jamur ini (Innocenti et al., 2009).

Senyawa 2-picolylamine memiliki ion molekul $\left(\mathrm{M}^{+}\right)$dengan $\mathrm{m} / \mathrm{z}$ yaitu 108 dan pola pemenggalan spektra seperti yang ditunjukkan pada Tabel 5.

Tabel 5. Pola fragmentasi pada senyawa 2-Picolylamine

\begin{tabular}{lllll}
\hline No. & $\mathbf{m} / \mathbf{z}$ & Kemungkinan fragmen yang hilang & & Penggalan \\
\hline $\mathbf{l}$ & 108 & $\mathrm{M}^{+}$ & & $\mathrm{C}_{6} \mathrm{H}_{8} \mathrm{~N}_{2}$ \\
\hline $\mathbf{2}$ & 106 & $\mathrm{M}^{+}-2$ & $-\mathrm{H}$ & $\mathrm{C}_{6} \mathrm{H}_{5} \mathrm{~N}$ \\
\hline $\mathbf{3}$ & 91 & $\mathrm{M}^{+}-15$ & $-\mathrm{NH}$ & $\mathrm{C}_{5} \mathrm{H}_{3} \mathrm{~N}$ \\
\hline
\end{tabular}

Pendekatan struktur ini dikonfirmasi dengan pola pemenggalan yang kemungkinan terjadi pada senyawa 2-Picolylamine sebagai berikut :

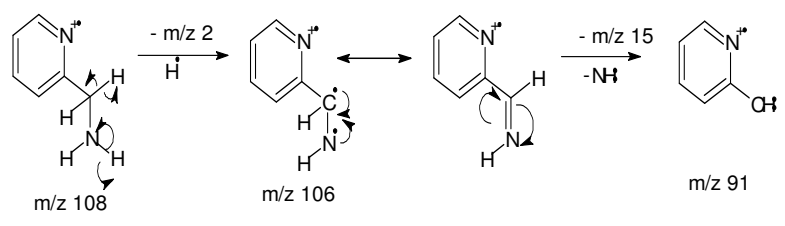

Meskipun ekstrak n-heksana daun cendana mengandung senyawa polifenol, alkaloid, dan terpenoid, kemungkinan yang paling berperan dalam menghambat 
pertumbuhan jamur adalah senyawa dari golongan alkaloid. Aktivitas antijamur senyawa alkaloid adalah dengan menghambat sistem respirasi sel serta proliferasi pembentukan protein, sehingga mengakibatkan kematian jamur. Komponen penyusun peptidoglikan pada dinding sel dirusak oleh senyawa alkaloid sehingga komponen tersebut tidak berbentuk utuh lagi. Dampak lain dengan adanya alkaloid adalah kebocoran membran sel dan hilangnya beberapa bahan intrasel seperti elektrolit (terutama senyawa kalium) dan molekul-molekul lainnya. Hal ini dapat mengakibatkan kerusakan dan kematian tetap pada sel jamur (Antonius dkk, 2017). Selain itu, menurut Wang et. al. (2014) hasil dari uji aktivitas senyawa alkaloid terhadap jamur invasif patogen $C$. albicans dan garis sel hati manusia normal menunjukkan selektivitas senyawa yang baik terhadap fitopatogenik jamur.

\section{SIMPULAN DAN SARAN}

\section{Simpulan}

Hasil penelitian menunjukkan bahwa ekstrak n-heksana, kloroform, dan n-butanol daun cendana (Santalum album L.) aktif sebagai antijamur terhadap jamur $C$. albicans dengan diameter daya hambat berturut-turut 13, 9, dan $8 \mathrm{~mm}$. Ekstrak n-heksana daun cendana (Santalum album L.) pada konsentarasi $80 \%$ menunjukkan daya hambat minimum dengan diameter hambat 9,32 $\mathrm{mm}$. Senyawa aktif antijamur yang terkandung pada ekstrak n-heksana daun cendana diduga benzofurazan dan 2-picolylamine .

\section{Saran}

Perlu dilakukan pemisahan, pemurnian dan uji aktivitas antijamur dan identifikasi isolat aktifnya.

\section{UCAPAN TERIMA KASIH}

Kepala beserta staff Lab. Kesehatan Daerah Provinsi Bali atas fasilitas laboratorium yang diberikan serta semua pihak yang telah membantu penelitian ini.

\section{DAFTAR PUSTAKA}

Ahsani, D. N. 2014. Respon Imun pada Infeksi Jamur. Jurnal Kedokteran dan Kesehatan Indonesia UII. 6 (2): 55-66.

Antonius, K. D. O., Herlambang P., dan Amalia S. S. D. 2017. Daya Hambat Pertumbuhan $C$. albicans dan Daya Bunuh $C$. albicans Ekstrak Daun Kemangi (Ocimum sanctum L.). Jurnal Wiyata. 4 (1): 78-83.

Balouiri, M., Moulay, S., dan Saad K. I. 2016. Methods for in vitro evaluating antimicrobial activity: A review, Journal Pharmaceutical Analysis. 6(2): 71-79.

Djunaedy, A. 2008. Aplikasi Fungisida Sistemik dan Pemanfaatan Mikoriza dalam Rangka Pengendalian Patogen Tular Tanah pada Tanaman Kedelai (Glycine max L.). J.Embryo. 5(2) : 1-9

Hanani, Y. 2014. Analisis Fitokimia: Penuntun Cara Modern Menganalisa Tumbuhan, a.b. Padmawinata, K. dan Soediro, L., Bandung: ITB.

Innocenti, A., Hall, R. A., Scozzafava, A., Mühlschlegel, F. A., Supuran., C. T. 2010. Carbonic Anhydrase Activators: Activation of $\beta$-Carbonic Anhydrase from Pathogenic Fungi $C$. albicans and Cryptococcus Neoformans With Amines and Amino Acids. Bioorganic and Medicinal chemistry. 18:10341037.

Monika, Moi, Y. 2017. Skrining Fitokimia, Uji Aktivitas Antioksidan dan uji Toksisitas Ekstrak Metanol Daun Cendana (Santalum album L.) Terhadap Artemia salina Leach. Tesis. Universitas Udayana, Bali

Mutiawati, V. K. 2016. Pemeriksaan Mikrobiologi pada C. albicans. Jurnal Kedokteran Syiah Kuala. 16(1): 53-63.

Puthera, A., Agung, G.N., dan Duniaji, A.S. 2007. Mempelajari Pengaruh Konsentrasi EkstrakRimpang Lengkuas (Alpinia galanga) Terhadap Pertumbuhan Aspergillus flavus pada KacangTanah (Arachis hypogaea L.). Labora Medika. 4(2): 131-136.

Rakesh, K., Nishat, A., and Tripathi, Y. C. 2015. Phytochemistry and Pharmacology of Santalum Album L: A Review. World Journal of 
Potensi Ekstrak Daun Cendana (santalum album L.) Sebagai Senyawa Penghambat Jamur Candida albicans (K. Swandiyasa, N. M. Puspawati, dan I. A. R. A. Asih)

Pharmaceutical Research. 4(10): 1842-1876.

Tripathi, K. D. 1999. Antifungal Drug In: Essential of Medical Pharmacology. 4th Edition. India: Jaypee Brothers Medical Publishers.

Wang, L., Ying-Ying, Z., Lei, W. 2014. Benzofurazan
Derivatives antifungal

agents Phytopathogenic fungi. European Journal of medicinal Chemistry. 80:535-542.

Waters Corporation. 2014. Waters Care and Use Manual: Oasis HLB Cartridges and 96Well Plate. Washington D.C: Waters Corporation. 